\title{
Correction to: Comparative analysis of chloroplast genomes of cultivars and wild species of sweetpotato (Ipomoea batatas [L.] Lam)
}

Shizhuo Xiao ${ }^{1+}$, Pan Xu ${ }^{2+}$, Yitong Deng ${ }^{1 \dagger}$, Xibin Dai ${ }^{1}$, Lukuan Zhao ${ }^{1}$, Bettina Heider ${ }^{3}$, An Zhang ${ }^{1}$, Zhilin Zhou ${ }^{1}$ and Qinghe $\mathrm{CaO}^{1 *}$

Correction to: BMC Genomics 22, 262 (2021)

https://doi.org/10.1186/s12864-021-07544-y

Following publication of the original article [1], the author's reported an error in the authorship list.

The name of Bettina Heider was incorrectly given as 'Bettina Heida'. The original article has been corrected.

\section{Author details}

'Jiangsu Xuzhou Sweetpotato Research Center/Sweetpotato Research Institute, China Agricultural Academy of Sciences, Xuzhou 221131, China. ${ }^{2}$ College of Pastoral Agriculture Science and Technology, Lanzhou University, Lanzhou 730020, China. ${ }^{3}$ International Potato Center, Av.La Molina 1895, La Molina, Lima, Peru.

Published online: 20 May 2021

\section{Reference}

1. Xiao S, Xu P, Deng Y, et al. Comparative analysis of chloroplast genomes of cultivars and wild species of sweetpotato (Ipomoea batatas [L.] Lam). BMC Genomics. 2021;22:262. https://doi.org/10.1186/s12864-021-07544-y.

\footnotetext{
The original article can be found online at https://doi.org/10.1186/s12864021-07544-y.

*Correspondence: cqhe75@yahoo.com

†'Shizhuo Xiao, Pan Xu and Yitong Deng contributed equally to this work. ${ }^{1}$ Jiangsu Xuzhou Sweetpotato Research Center/Sweetpotato Research Institute, China Agricultural Academy of Sciences, Xuzhou 221131, China Full list of author information is available at the end of the article
}

(c) The Author(s). 2021 Open Access This article is licensed under a Creative Commons Attribution 4.0 International License, which permits use, sharing, adaptation, distribution and reproduction in any medium or format, as long as you give appropriate credit to the original author(s) and the source, provide a link to the Creative Commons licence, and indicate if changes were made. The images or other third party material in this article are included in the article's Creative Commons licence, unless indicated otherwise in a credit line to the material. If material is not included in the article's Creative Commons licence and your intended use is not permitted by statutory regulation or exceeds the permitted use, you will need to obtain permission directly from the copyright holder. To view a copy of this licence, visit http://creativecommons.org/licenses/by/4.0/ The Creative Commons Public Domain Dedication waiver (http://creativecommons.org/publicdomain/zero/1.0/) applies to the data made available in this article, unless otherwise stated in a credit line to the data. 